\title{
What Are the Motivation and Barriers of Young Farmers to Enter the Sector?
}

\author{
Marie Šimpachová Pechrová ${ }^{1}$, Ondřej Šimpach², Tomáš Medonos ${ }^{1}$, Daniela Spěšná ${ }^{1}$, Miloslav Delín ${ }^{1}$ \\ ${ }^{1}$ Institute of Agricultural Economics and Information, Prague, Czech Republic \\ ${ }^{2}$ University of Economics Prague, Czech Republic
}

\begin{abstract}
Ensuring the generation renewal in the agriculture is crucial. There are policy incentives to attract young people, but the motivation to enter the sector depend on many factors and there are also barriers. The aim of the paper is to assess the motivation and barriers of the young farmers, newcomers to the agrarian sector in the Czech Republic and to draft the conclusions for policy and incentives creation.

Based on answers of 510 young farmers, the main motive to enter was the wish to continue with farming on the farm of the parents or other relatives and to work in nature and with animals. The hardest was to purchase the agricultural land, administrative burden and ensuring the finances for the development and for start-up. Hence, to facilitate the start-up it is useful to support the land purchase and provide investment subsidies. The research was financed from internal research project 1113/2018.
\end{abstract}

\section{Keywords}

Common Agricultural Policy, enter barriers, motivation, young farmers.

Šimpachová Pechrová, M., Šimpach, O., Medonos, T., Spěšná, D. and Delín, M. (2018) "What Are the Motivation and Barriers of Young Farmers to Enter the Sector?", AGRIS on-line Papers in Economics and Informatics, Vol. 10, No. 4, pp. 79-87. ISSN 1804-1930. DOI 10.7160/aol.2018.100409.

\section{Introduction}

"Young farmers problem" is well acknowledged in the European Union (EU). Policy makers are concerned about decreasing number (and share) of young farmers. In 2016, there were on average $10.6 \%$ of farmers younger than 40 years in EU-28, but $32.8 \%$ older than 65 years, i.e. in retirement age (Eurostat, 2018). In the Czech Republic (CR), there were $10.2 \%$ of young farmers and $26.8 \%$ of retired. Rovný (2016) found a negative correlation between young farmers under 35 years and old farmers above 55 years in years 2007 and 2010 in the EU. Further projection of age-and-sex structure done for the CR by Šimpach and Pechrová (2015) is also not positive. They deducted the development of the agricultural population from the trends in total population and predicted that the number of agricultural workers older than 55 years will exceed the number of young in 2026.

"The lack of young farmers puts under risk the survival of the sector itself, due to an inadequate rate of generational turnover in the sector." (Kontogeorgos et al., 2014) According to Zagata and Sutherland (2015) "young sole holders on average operate more economically robust farms than their older counter-parts." Similarly, Galanopoulos et al. (2011) see as the main reason of poor adoption levels of novel production techniques and improved management systems the fact that the farmers at transhumance sheep and goat farms are old and lack the successors. However, according to Davis, Caske and Wallace (2009) only simple replacement of old farmers by young ones would not bring any significant improvement of the company's performance. Nevertheless, young farmers "have a longer planning horizon and tend to invest more heavily in business growth than comparable older age groups" (Davis, Caske and Wallace, 2013). They also tend to be more technically efficient as showed by Pechrová (2015a), but the differences were not statistically significant.

Despite that young farmers are well studied on EU level (e.g. Zagata et al., 2017), detailed study on the $\mathrm{CR}$ is missing. Therefore, the aim of the paper is to assess the motivation and barriers of young farmers in the CR to enter the sector. In the next section we provide the literature review of the main motivators or barriers when setting up 
a new business. Next section describes the data and methods. Then the results are presented and discussed. Final section concludes and suggests policy implications.

\section{Motivation and barriers to enter the agricultural sector}

The identification of the main motives and barriers for our research was based on literature review and work of Šimpachová Pechrová (2017). We identified and 9 motives and 15 barriers.

Renko and Freeman (2017) proclaimed that "the most commonly thought-of motivation for starting a new business, financial motivation, involves reasons for entrepreneurship that relate to individual's intention to earn money and achieve financial security." We also included the "Way of ensuring the income" as one of the motives. In accordance with a trend of a healthy / organic food, we can also consider as a motive also "Way of ensuring the food for own family". Another motive is "To be an independent entrepreneur" related with the possibility to put into practice personal skills and capabilities to run own business which was identified by de Silva Moreira Ferreira, Loiola, and Guedes Gondim (2017) as one of the motive for the entrepreneurial career of the university students in Brazil. Besides, Renko and Freeman (2017) also highlight the importance of the individual opportunity nexus in entrepreneurship. Young people from agricultural family probably have a motive to start in agriculture to "Continue with farming on the farm of the parents or other relatives". There are also other factors - e.g. Zhao, Seibert and Lumpkin (2010) found that personality plays a role in the emergence and success of entrepreneurs.

Agricultural sector is specific due to biological processes in the production, spatial and seasonal character of production, influence of the natural factors on the process and output of production (Homolka, Pletichová and Mach, 2008). The character of the work determines the motivation (demotivation) to enter the sector. Young people might be motivated to "Work in the nature", "Work with the animals" or by their "Interest in modern technologies" as many advanced technologies that facilitate the work in agriculture are available.

There are "Subsidies for start-up and development of agricultural activities" provided from RDP and "Increased direct subsidies for young farmers" provided under the Pillar I of CAP. The measure Setting up of new farmers "has the objectives of facilitating new farmers' initial establishment and the structural adjustment of their holdings after initial setting up. Beneficiaries have to be less than 40 years of age, set up for the first time as head of an agricultural holding; possess adequate occupational skills and competence; and submit a business plan for the development of their farming activity" (Kontogeorgos et al., 2014).

Regarding the main barriers Šmpachová Pechrová (2017) identified that the main issue is the access to land and credits. "Additionally, CAP support pushes up land prices and thus adds to the time required for new entrants who are not inheriting to put together the necessary capital. Consequently, it gives an incentive to older farmers to hold on to their land in order to receive the single farm payment" (Kontogeorgos et al., 2014). Also Matthews (2013) names main difficulties with start in agriculture. We included the barriers related to finances: "Obtaining finance for business startups", "Obtaining finance for business development"; and to obtaining of production factors: "Purchase of agricultural land", "Lease of agricultural land", "Purchase of livestock", "Purchase of buildings", "Lease of buildings", "Purchase of other tangible assets (machinery)", "Lease of other tangible assets".

Each firm shall have a business plan that includes "aims of the organization, strategy of the organization and projects that are about to be realized in period. (Kovář, Hrazdilová Bočková, 2016) However, "Strategic planning (what to manufacture for whom)" and "Ensuring sales" can be difficult, especially for newcomers, but also young people, who inherited the farm usually want to make some changes in the production. Not all farmers have managerial skills and they lack experience with strategy planning. Farmers can also "lack knowledge and experience" in many other fields and obtaining them can be problematic.

Besides, a personal planning is needed. In small agricultural holdings, it is usually a family work force working on the farm, but in the CR it is not an exception that a young farmer overtakes large farm To "Obtain the qualified / unqualified workers" is important. Personal planning ensures that the firm has enough workforce, with needed knowledge, experiences and skills, with desirable personal features and characteristics, and work attitude, and right motivation, flexible, on the right time with adequate costs (Kovář, Hrazdilová Bočková, 2016).

With founding of a firm are linked also certain administrative tasks and needs to comply with veterinary laws or laws on the environment protections etc. Hence, there is "Administrative 
burden" and related controls from responsible bodies.

\section{Materials and methods}

Motives and barriers stated in previous chapter were included into the questionnaire. We held quantitative primary survey from 15 June to 1 July 2018 on a sample of young farmers that was obtained from Land Parcel Identification System (LPIS) database from which were selected farmers younger than 40 years and from the database of subsidy recipients. Both databases were provided by Ministry of Agriculture. Hence, we had contacts on both, on financially supported and non-supported farmers. The questionnaire was distributed in electronical version programmed in Google form by the link in the e-mail to the respondents. It was strictly anonymous. Answers were collected via Google form and it was not possible to identify the farmer. We asked over 6000 respondents and collected 510 completely filled-in questionnaires.

\section{Data}

One quarter of the respondents were women. Average age was 33 years. Mostly, the household of the farmers had 4 members including the farmer (in $39.4 \%$ cases). Then there was $20 \%$ households with 3 members (probably families with one children), $16.5 \%$ with $5,11.0 \%$ with 2 members and $4.1 \%$ with 1 member. $8.8 \%$ of farmers indicated larger household, probably because they included also parents or grandparents living with them.

Mostly the respondents (43.5\%) graduated from high school with leaving exam, 32.9\% had the university. It shows that the educational structure of the young farmers is relatively high. It is in line with total educational structure of farm managers (see Eurostat (2017) for the data of 2013) where farmers younger than 35 years have mostly, in $45.0 \%$ cases full agricultural training and then in $36.7 \%$ practical experiences only. In comparison with other age categories, it is the only one, where most members have the highest grade of agricultural education.

$94.7 \%$ of respondents were physical persons and $4.7 \%$ limited liability companies. The size of the agricultural holdings was relatively large -42.4 ha on average, from which $62.4 \%$ (26.4 ha) was rented. The median of the acreage was, however, much lower - only 18 ha of UAA (Utilized Agricultural Area), from which 8 ha were rented. It therefore visible that the division of land between enterprises is uneven, there is a relatively small number of large holdings which diverge the average upwards and a large number of smaller enterprises. There were farmers without land and maximal acreage was 1000 ha. Majority of respondents were new agricultural entrepreneurs registered in 2015 (20\%) and 2016 (19.8\%). Most of them started their farming activities already in the year when they registered (80.4\%). The average existence of an enterprise since registration was almost 5 years (4.9), but the median was only 3 years. Young farmers' businesses operated on average for 5.2 years, but half of them only 3 years. Over one fourth of the holdings $(26.5 \%)$ was organic farmers. They employed mostly only 1 (in $45.3 \%$ of cases) or none employee $(42.0 \%)$. From this amount there were mostly $(63.5 \%)$ no employees from the family or only 1 (29.4\%). An average firm employed 0.89 worker, but $50 \%$ of firms employed 1 person. The average number of family workers was lower (0.56).

\section{Methods}

The questionnaire consisted of several parts: data about the agricultural holding and type of start-up, motivation, barriers, and data about farmers.

A scale from 1 point (Certainly important / Certainly yes), 2 points (Rather important / Rather yes) to 3 points (Rather unimportant / Rather not), 4 points (Certainly unimportant / Certainly not) and 0 point (I cannot assess) was used to assess motivation and barrier, respectively. The weighted average mark was calculated (answers with 0 were excluded). The lower was the score, the more important motivation or barrier was for the farmer. Similar approach was also used to evaluate the contribution of subsidies to facilitate the startup. At the scale 0 points meant that the respondent did not receive the subsidy and could not evaluate its contribution.

The data are described using arithmetic mean, median and histograms. The answers are grouped in contingent tables in MS Excel and it is tested, whether the motivation to start with agriculture or the barriers depends on the gender or on the type of start-up - overtaking the farm / starting with certain background or starting a new farm. We used $\chi^{2}$ goodness of fit test where null hypothesis is independence of the variables $\left(\mathrm{H}_{0}: \pi_{\mathrm{ij}}=\pi_{\mathrm{i}} \cdot \pi_{\mathrm{j}}\right.$; where $1 \leq i \leq r, 1 \leq \mathrm{j} \leq s)$. When the calculated test criterion $G$ (1) exceeds or is equal to the critical value of the test on level of significance $\alpha=0.05$ and degrees of freedom $v=(r-1)(s-1), \mathrm{H}_{0}$ is rejected and alternative hypothesis retain $\left(\mathrm{H}_{\mathrm{A}}\right.$ : non $\left.\mathrm{H}_{0}\right)$. 
$G=\sum_{i=1}^{r} \sum_{j=1}^{s} \frac{\left(n_{i j}-n_{i j}^{\prime}\right)^{2}}{n_{i j}^{\prime}} G \approx \chi^{2}[(r-1)(s-1)]$

where $r$ represents the number of rows and $s$ $W_{\alpha}=\left\{G ; G \geq \chi_{1-\alpha}^{2}\right\}$ of columns in contingence table. Critical field is . If there is a dependence of two features, it can be calculated an intensity of this dependence by Cramer contingence coefficient $V$ (2). The maximum value of this coefficient is derived from the dimension of the contingency table.

$$
V=\sqrt{\frac{\chi^{2}}{n(q-1)}} \quad q=\min \{r, s\}
$$

\section{Results and discussion}

There were different ways of starting up of the farming stated by the farmers (besides 5 pre-defined options) - see Figure 1. 42.4\% of young farmers started farming without previous background and $41.8 \%$ took it over from parents or other relatives. The takeover was not always complete, as some farmers started operating only with little background. The farms were gained by inheritance in $5.1 \%$ cases and $4.1 \%$ of respondents bought the farm from parents or other relatives and $1.8 \%$ from other farmers. 6 respondents also joined in a various form to the existing family holding and the same number of respondents partly took over the holding from parents or other relatives. 5 already had their own background from elsewhere. In addition, 3 young starting farmers rented land from their parents or other relatives and 2 from other farmers. $29.0 \%$ of farmers overtook the farm from a farmer older than 55 years. In $46.1 \%$ of cases the farmers started farming up to 10 years since the graduation.
Then $31.0 \%$ of farmers started later and $22.9 \%$ of farmers already during studies.

\section{Motivation}

Regarding the motivation for the start-up, there were 9 reasons stated and evaluated by the farmers on the scale from, 1 - Certainly important to 4 - Certainly unimportant $(0-I$ cannot assess). The results are displayed at Figure 2. For $42.2 \%$ of respondents was important to continue with the farming of their parents or relatives, $12.9 \%$ considered this option as rather important, $5.5 \%$ as rather unimportant, $2.7 \%$ as certainly unimportant, $36.7 \%$ could not assess this type of motivation as it was irrelevant for them.

Agriculture as a way of ensuring income was rather important (in $35.3 \%$ of cases), but certainly important only in $30.2 \%$ of cases. Similarly, the way of ensuring food for the family was certainly important for less than a third (31.8\%) of respondents. Almost half (49.0\%) considered it to be an important motivation to be an independent entrepreneur. But the majority of young people was attracted to work in nature (it was certainly important for $59.2 \%$ of them and rather important for $27.8 \%$ ). Similarly, work with animals was crucial for more than half of respondents $(52.2 \%)$. On the other hand, the interest in modern technologies in agriculture was not so important (roughly one-fourth of the respondents replied that this theme was of certain importance for them, $25.7 \%$ rather important and $26.5 \%$ rather unimportant).

Subsidies did not emerge as one of the important motives. For $26.9 \%$ of the respondents were rather important and $23.1 \%$ certainly important. Almost 14\% did not assess it and for over 14\% were certainly unimportant. A similar distribution

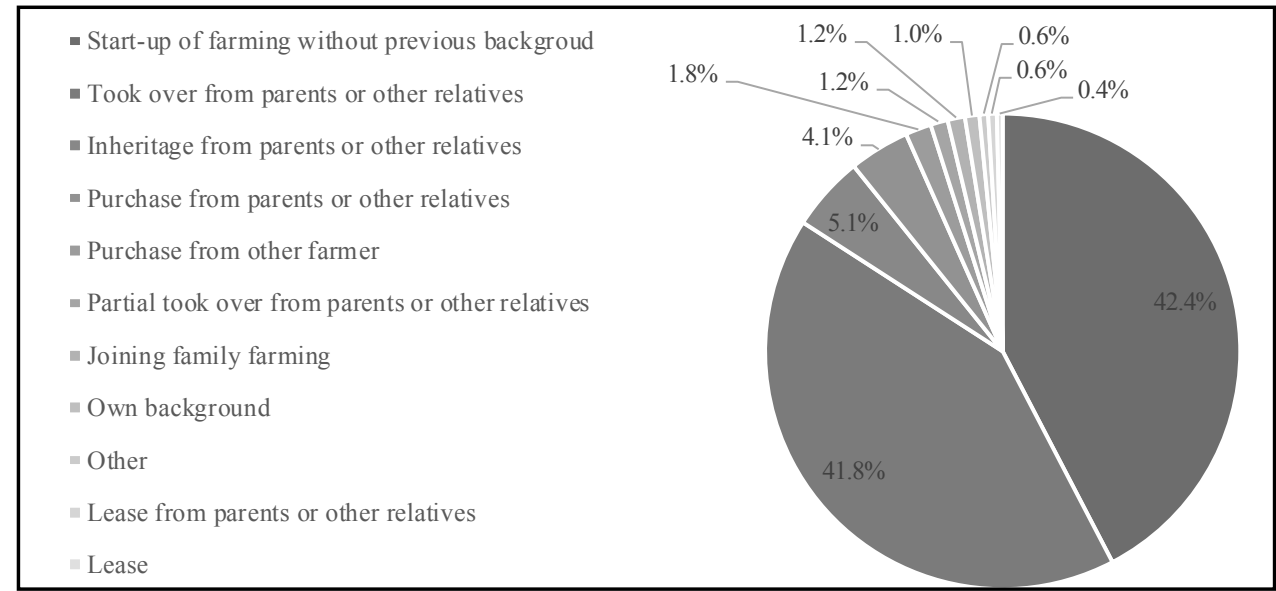

Source: own elaboration

Figure 1: Ways of start-up of young farmers. 


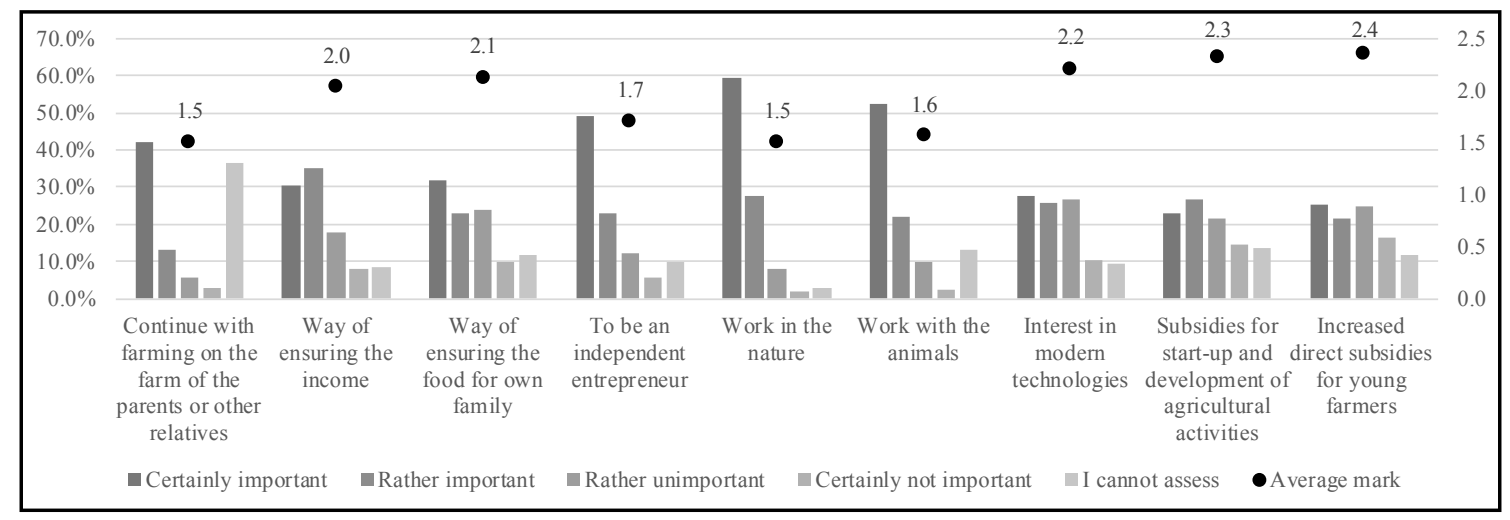

Source: own elaboration

Figure 2: Motivation of young farmers to enter the agricultural sector.

of responses was also for the increase in direct payments for young farmers, which were certainly important in $25.5 \%$ of cases and rather important in $21.6 \%$ of cases. Nearly for a quarter of young farmers $(24.7 \%)$ it was rather unimportant and for $16.5 \%$ certainly unimportant and for $11.8 \%$ this was irrelevant. The finding is in line with the proclamation of Carbone and Subioli (2008) for the case of Italy: “... the size of the payment provided by the EU measure for young farmers offers an ineffective incentive to attract young people into the sector, and it is also insufficient to finance an increase in the competitiveness of the existing holdings through the familiar turnover within the farm".

Based on the average mark (see Figure 2) the most prevalent motive was the continuation of parents' farming followed by work in nature or work with animals. On the contrary, subsidies were not so strong motive (although the average over 2 means that the respondents moved on the border between Rather important and Rather unimportant with the important prevailing).

Farmers also stated other reasons that were not included in the close question. The most frequent answers were "I like it", "I am enjoying it", "It is my hobby", "I like animals", "I like horses", "I like nature" or "family tradition" which points on the strong relation of the young people towards the agriculture and nature. The other motives were mainly intrinsic (coming from inside of the people) which are hard to be influenced.

It was tested, whether the motivation depends on the gender and type of the start-up. Research of Hazudin et al. (2015) indicated that women are more likely to engage in business if their family matters still can be prioritized and that it is more challenging for them to succeed in without knowledge and skills competency. We also suppose that there might be differences. Continue with farming on the farm of the parents or other relatives depends on the gender, similarly as the work with animals (when it can be supposed that women have warmer relation towards certain animals such as horses). Interest in modern technologies, on the other hand, was a domain of men.

Continue with farming on the farm of the parents or other relatives dependent on the type of startingup as same as the way of ensuring the income and food. It can be supposed that farmers with background from a family feel that it is important for them to continue with family business. They also perceive that it is possible to have an income from agriculture and food from home production that ensures their living. The differences were also in the interest in modern technologies, where people with background perceive it as more important. The subsidies also depend on whether the farmer overtook the farm, or he started without previous background. Crammers' $V$ was 0.14 and pointed out on weaker dependence.

\section{Barriers}

Main barriers were related to the obtaining of production factors. Results are displayed at Figure $3 \mathrm{a}$ and $3 \mathrm{~b}$. Purchase of agricultural land and obtaining the finances for start-up of the business was a problem for $62.2 \%$ and $52.2 \%$ of respondents, respectively. Also purchase of tangible assets (machinery) was important for $40.0 \%$ of respondents. Besides, administrative burden was a great barrier for $62.0 \%$ of starting young farmers. Strategic planning was certainly a barrier only for $16.7 \%$ of respondents. $21.4 \%$ considered that it is rather a barrier, but for the rest it was not a problem and it could not be assessed by $8.2 \%$. Obtaining the finances for a start-up was certainly $(52.2 \%)$ and rather 
$(26.5 \%)$ problematic as same obtaining the finances for the development $(49.8 \%$ - certainly yes and $33.9 \%$ - rather yes). Only about $4.1 \%$ of respondents did not need finances for their start-up.

Lease of agricultural land was less problematic (42.5\% - certainly yes and $26.9 \%$ - rather yes) than its purchase $(62.2 \%$ - certainly yes and $15.5 \%$ - rather yes), but $15.7 \%$ (10.4\%, respectively) farmers did not need agricultural land. Purchase of livestock was rather not a problem in 33.3\% cases and certainly not a problem in $16.3 \%$. $19.4 \%$ of farmers did not solve this issue at all. Similar share of young farmers that consider the purchase of the buildings as certainly problematic (29.6\%) did not have to buy them at all $(28.6 \%)$. While lease of the buildings was certainly a problem for $21 \%$ of respondents, it was rather not problematic for $21.4 \%$ and $34.9 \%$ did not have to solve it at all. Purchase of tangible assets was a problem for $40.0 \%$ (certainly yes) and $27.8 \%$ (rather yes) farmers. Lease was not problematic, but mainly due to the fact that $36.3 \%$ of respondents did not have to solve this problem.
Obtaining the workers was according to the expectations not that important, because, the holdings were mainly small or used family labour. $48.4 \%$ did not need qualified workers and $52.2 \%$ unqualified workers. If they needed them, non-qualified workers were easier to obtain. To ensure sales was rather not a problem for $30.0 \%$ of farmers, but for 25.30 it was rather a and for $17.6 \%$ it was certainly a problem. Many farmers see as problematic an administrative burden (60.2\% - certainly yes, $20.8 \%$ - rather yes).

Obtaining the knowledge and experience was rather important for $25.9 \%$, but rather unimportant for $35.3 \%$. We must note that only people who actually started the activity were questioned. There are graduates from high schools or universities who did not enter the sector at all for various reasons. For example, Khayri, Yaghoubi and Yazdanpanah (2011) identified barriers to enhance entrepreneurship in the agricultural higher education.

The highest average mark (1.3) was given just to purchase of agricultural land and 1.5

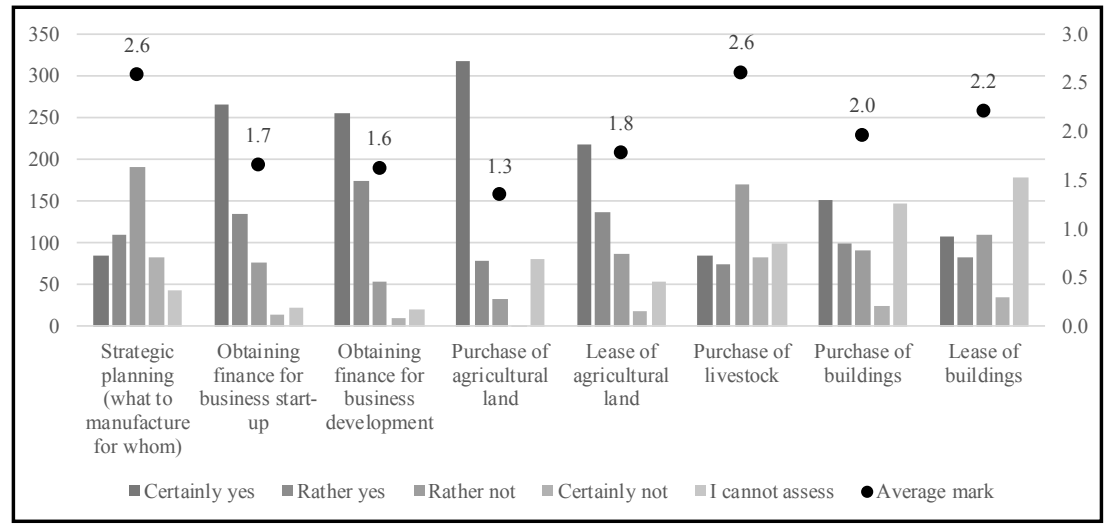

Source: own elaboration

Figure 3a: Barriers of young farmers to enter the agricultural sector (part 1).

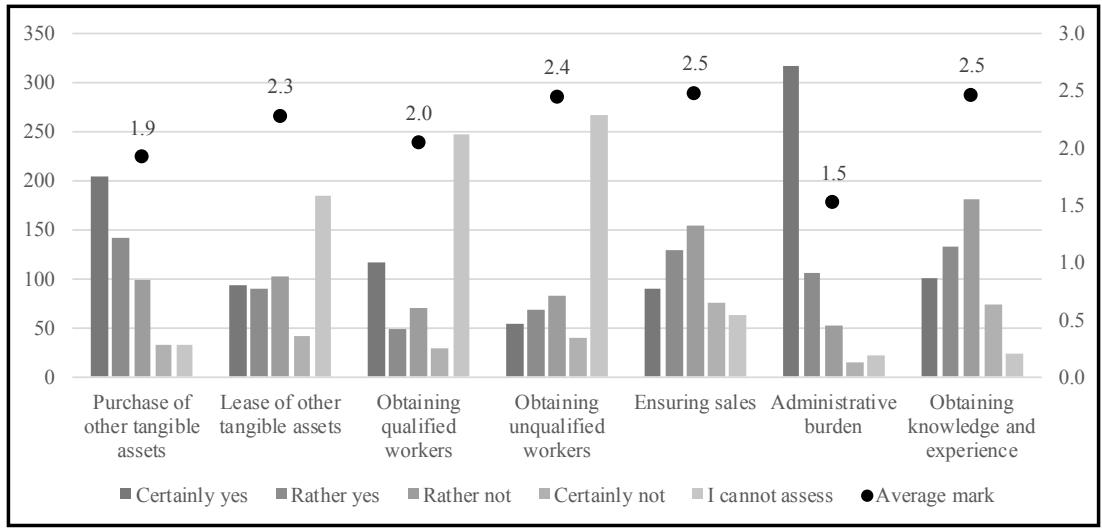

Source: own elaboration

Figure $3 \mathrm{~b}$ : Barriers of young farmers to enter the agricultural sector (part 2). 
to administrative burden. On the other hand, strategic planning and purchase of livestock (2.6) were seen as less problematic.

From other barriers were mainly stated again the "administrative and bureaucracy" - related to subsidies, setting-up of the firm, register the animals etc. Then again the "financing" and "investments", "obtaining the land", "legislation" in the CR such as building law etc.

Crammers' $V$ was 0.14 and pointed out on weaker dependence between barriers and gender or type of start-up. Strategic planning depends on the gender as same as the lease of agricultural land. It seems that women have more problems with planning, but less with a lease of a land. Regarding the type of start-up, we originally assumed that there might be strong dependence between the type of start-up and the barriers - probably those farmers, who started with certain background might have their way easier and the barriers shall not be that pronounced, but we found only the dependence in obtaining finance for business start-ups.

Research by Zondag et al. (2016) revealed that among five most important general needs of young farmers belong availability of land to buy, land to rent, subsidies, access to credit and qualified labour (that was more important in new MS than in EU 15). This is in line our findings where the lack of available land and the ensuring of finances was seen as a main problem. Besides, Zondag et al. (2015) identified that Czech farmers lack the experience with multi-generational farming and knowledge and experience in the management of plant growing and/or animal breeding.

Results can be considered during formulation of the measures and incentives. However, we the survey was done only on 510 young farmers (despite that we asked over 6 thous. respondents). It is difficult to assess whether this is representative sample as its consistence is purely random. In future research we would like to focus on case studies on the farms and perform face-to-face interviews with the farmers to find out more about the incentives that could help them when they were starting their business and what was their major motivation.

\section{Conclusion}

Generation renewal in agriculture is crucial and shall be supported. The motivation of young people to enter the sector depend on many factors. On the other hand, there are barriers that are sometimes too hard to overcome. The aim of the paper was to assess the motivation and barriers of the young farmers in the CR and to draft the conclusions for policy and incentives creation. Based on the data from a primary survey among 510 young farmers we found that the main motive to enter the agriculture was the wish to continue with farming on the farm of the parents or other relatives and to work in nature and with animals. Opposite, the hardest was to purchase the agricultural land, administrative burden and ensuring the finances for the development and for start-up.

The results of the analysis could be of use for the design of Common Agricultural Policy in the next programming period 2020-2027. To facilitate the start-up of young farmers, it is useful to support the purchase of the land. It is currently done by Supporting and Guaranteeing Agricultural and Forestry Fund in the CR which subsidies the interests of a loan for the purchase of land. Besides, there are investment subsidies for a setting up of young farmers or increased direct payments from Common Agricultural Policy that can help them with the start-up. However, the necessity of business plan (that is often difficult for farmers to assemble), long demanding administration process and related requirements (minimal and maximal standard production of the farm etc.) there are difficult to be obtained by young farmers. In this case an advisory system shall play its role. There are certified advisors by the Ministry of Agriculture, but the young farmers shall get used to use the agricultural extension services.

\section{Acknowledgements}

The research was funded from Internal research project of the Institute of Agricultural Economics and Information No. 1113/2018.

\section{Corresponding authors}

Ing. Marie Šimpachová Pechrová, Ph.D.

Institute of Agricultural Economics and Information, Mánesova 1453/75, 12000 Prague, Czech Republic

Phone: +420 720238 268, Email: Simpachova.Marie@uzei.cz 


\section{References}

[1] Carbone, A. and Subioli, G. (2008) "The generational turnover in Agriculture: the ageing dynamics and the EUR support policies to young farmers", In: 109 ${ }^{\text {th }}$ EAAE Seminar: The CAP after the Fischler reform, pp. 1-19. [Online]. Available: http://ageconsearch.umn.edu/record/44731/ files/A074_Carbone.pdf [Accessed: 1 Aug. 2018].

[2] da Silva Moreira Ferreira, A., Loiola, E. and Guedes Gondim, S. M. (2017) "Motivations, business planning, and risk management: entrepreneurship among university students", RAI Revista de Administração e Inovação, Vol. 14, No. 2, pp. 140-150. ISSN 1809-2039. DOI 10.1016/j.rai.2017.03.003.

[3] Davis, J., Caskie, P. and Wallace, M. (2009) "Economics of farmer early retirement policy", Applied Economics, Vol. 41, No. 1, pp. 35-43. ISSN 0003-6846. DOI 10.1080/00036840600994211.

[4] Davis, J, Caskie, P. and Wallace, M. (2013) "Promoting structural adjustment in agriculture: The economics of New Entrant Schemes for farmers", Food Policy, Vol. 40, pp. 90-96. ISSN 0306-9192. DOI 10.1016/j.foodpol.2013.02.006.

[5] Eurostat (2017) "Agricultural training of farm managers: number of farms, agricultural area, labour force and standard output (SO) by age and sex of the manager [ef_mptrainman]". [Online]. Available: http://appsso.eurostat.ec.europa.eu/nui/show.do?dataset=ef_mptrainman\&lang=en [Accessed: 1 Aug. 2018].

[6] Eurostat (2018) "Farm indicators by agricultural area, type of farm, standard output, sex and age of the manager and NUTS 2 regions [ef_m_farmang]". [Online]. Available: http://appsso.eurostat. ec.europa.eu/nui/show.do?dataset=ef_m_farmang\&lang=en [Accessed: 1 Aug. 2018].

[7] Galanopoulos, K., Abas, Z., Laga, V., Hatziminaoglou, I. and Boyazogluc, J. (2011) "The technical efficiency of transhumance sheep and goat farms and the effect of EU subsidies: Do small farms benefit more than large farms?", Small Ruminant Research, Vol. 100, No. 1, pp. 1-7. ISSN 0921-4488. DOI 10.1016/j.smallrumres.2011.05.008.

[8] Hazudin, S. F., Kader, M., Tarmuji, N. H., Ishak, M. and Ali, R. (2015) "Discovering Small Business Start up Motives, Success Factors and Barriers: A Gender Analysis”, Procedia Economics and Finance, Vol. 31, pp 436-443, ISSN 2212-5671. DOI 10.1016/S2212-5671(15)01218-6.

[9] Homolka, J., Pletichová, D. and Mach, J. (2008) "Zemědělská ekonomika" ("Agricultural Economics", In Czech), Czech University of Life Sciences Prague. ISBN 978-80-213-1830-4.

[10] Khayri, S., Yaghoubi, J. and Yazdanpanah, M. (2011) "Investigating barriers to enhance entrepreneurship in agricultural higher education from the perspective of graduate students", Procedia Social and Behavioral Sciences, Vol. 15, pp. 2818-2822. ISSN 2212-5671. DOI 10.1016/j.sbspro.2011.04.195.

[11] Kontogeorgos, A., Michailidis, A., Chatzitheodoridis, F. and Loizou, E. (2014) "New Farmers" a Crucial Parameter for the Greek Primary Sector: Assessments and Perceptions", Procedia Economics and Finance, Vol 14, pp. 333-341. ISSN 2212-5671. DOI 10.1016/S2212-5671(14)00721-7.

[12] Kovář, F. and Hrazdilová Bočková, K. (2016) “Konkurenceschopný podnik: ekonomika konkurenceschopného pondniku” (In Slovak), DTI University, Dubnica nad Váhom. ISBN 978-80-7512-608-5.

[13] Matthews, A. (2013) “Wasting Money on Young Farmers?”, CAP Reform.eu, May 27, 2013 [Online]. Available: http://capreform.eu/wasting-money-on-young-farmers/ [Accessed: 1 Aug. 2018].

[14] Pechrová, M. (2015b) “The profitability and technical efficiency of young farmers supported from Rural Development Programme", In: 33 ${ }^{\text {rd }}$ International Conference on Mathematical Methods in Economics (MME), pp. 618-623. ISBN 978-80-261-0539-8.

[15] Pechrová, M. (2015a) “The Technical Efficiency of Young Farmers in the Czech Republic", In: $9^{\text {th }}$ International Days of Statistics and Economics (MSED), pp. 1262-1269. ISBN 978-80-87990-06-3. 
[16] Renko, M. and Freeman, M. J. (2017) "How motivation matters: Conceptual alignment of individual and opportunity as a predictor of starting up", Journal of Business Venturing Insights, Vol. 8, pp. 56-63. ISSN 2652-6734. DOI 10.1016/j.jbvi.2017.06.003.

[17] Rovný, P. (2016) "The Analysis of Farm Population with Respect to Young Farmers in the European Union", Procedia - Social and Behavioral Sciences, Vol. 220, pp. 391-398. ISSN 1877-0428. DOI 10.1016/j.sbspro.2016.05.513.

[18] Šimpach, O. and Pechrová, M. (2015) "Development of the Czech Farmers' Age Structure and the Consequences for Subsidy Policy", AGRIS on-line Papers in Economics and Informatics, Vol. 7, No. 3, pp. 57-69. ISSN 1804-1930.

[19] Šimpachová Pechrová, M. (2017) "What is the motivation and barriers for young people to enter the agricultural sector?", In: The 10 $0^{\text {th }}$ International Scientific Conference RELIK 2017 (Reproduction of Human Capital - mutual links and connections), pp. 454-461. ISBN 978-80-245-2238-8.

[20] Zagata, L., Hrabák, J., Lošták, M., Bavorová, M., Ratinger, T., Sutherland, L.-A. and McKee, A. (2017) "Research for AGRI Committee - Young farmers - Policy implementation after the 2013 CAP reform", European Parliament, Policy Department for Structural and Cohesion Policies, Brussels, pp. 1-78. ISBN 978-92-846-2027-2. DOI 10.2861/536526.

[21] Zagata, L. and Sutherland, L.-A. (2015) "Deconstructing the 'young farmer problem in Europe': Towards a research agenda", Journal of Rural Studies, Vol. 38, pp. 39-51. ISSN 0743-0167. DOI 10.1016/j.jrurstud.2015.01.003.

[22] Zhao, H., Seibert, S. E. and Lumpkin, G. T. (2010) "The Relationship of Personality to Entrepreneurial Intentions and Performance: A Meta-Analytic Review", Journal of Management, Vol. 36, No. 2, pp. 381-404. ISSN 0149-2063. DOI 10.1177/0149206309335187.

[23] Zondag, M.-J., Koppert, S., de Lauwere, C., Sloot and P. Pauer, A. (2016) "Needs of young farmers. Report I of the Pilot project: Exchange programmes for young farmers", Luxembourg: Publications Office of the European Union, pp. 1-79. ISBN 978-92-79-50608-6. DOI 10.2762/13075. 